\title{
THE DEVELOPMENT OF SMART, MOBILE AND INTERACTIVE LEARNING (SMILE) MODEL
}

\author{
${ }^{1}$ Mariana Susanti and ${ }^{2}$ Suparti \\ Balai Pengembangan Media Radio Pendidikan dan Kebudayaan \\ Kementerian Pendidikan dan Kebudayaan Republik Indonesia \\ ${ }^{1}$ mariana.susanti@kemdikbud.go.id ²suparti@kemdikbud.go.id
}

\section{Abstract}

Indonesian citizen experience a fast changing lifestyle related to information and communication technology (ICT) utility, such as gadget and Internet. Unfortunately, the use of the Internet in Indonesia for educational purposes is mostly focused on reading articles and viewing tutorial videos. The superiority of audio media is in language learning, especially to develop listening and speaking skills. Therefore, in 2017 BPMRPK designed a model of offline interactive learning audio media for high school/vocational level English conversation. The formulation of the problem in this design: "How to provide an alternative English conversation learning for senior high/vocational school students using interactive and offline audio media?" Therefore, this interactive English conversation learning model was developed to: 1) become an alternative learning media for high school/vocational high school students in interactive and offline English conversation; and 2) increase the feeling of pleasure and confidence for high school / vocational high school students to learn English conversation through this media.

The development of this learning model uses the approach of constructivism theory that focuses on students so that they are able to learn independently, form knowledge through experience and cognitive interaction, and finally rearrange knowledge continuously through the reconstruction phase. The smart mobile interactive learning (SMILE) application is an English conversation application that can run on the Android operating system and is built based on the stages of application development (planning, analysis, design, implementation and maintenance). SMILE uses voice recognition technology. The SMILE model refers more to the communicative approach based on the types of expressions taught for high school/ vocational high school students in accordance with the English 2013 curriculum. The types of expressions referred to are wrapped in topics / themes that are close to the lives of high school/vocational high school students. From the needs analysis of this English conversation application model, the results of processing data from teacher and student respondents indicate that the SMILE application is easy to learn, the content is easy to understand, the menu display is quite memorable. The availability of voice command and voice instruction in the SMILE application, according to most teacher and student respondents, is easy to use, even though the demonstration that is demonstrated is not perfect. When entering the production 
stage, there are a number of conditions for entering audio into the application program language. This is because between audio and program language must be appropriate so as not to confuse users. The pattern of using the Smile application is the potential users download the SMILE application through Google PlayStore. The developer only needs an email address to find out if the downloader is human, and not a robot. When downloading, users need to have adequate internet connection support. But when using the Smile application, users can use offline/offline. Users use the SMILE app in sequence, starting from the standard opening section, category and lesson sections, full conversation sections, vocabulary and expression sections, role playing sections, review sections (users can listen to their voice recordings, and then decide whether to save or delete that records), and the praise section. The evaluation phase that will be carried out in the SMILE application is the prototype evaluation and model evaluation.

Keywords: learning, audio, application,conversation

\section{INTRODUCTION}

The development of information, communication and technology from year to year has increased and provided a lifestyle change and human viewpoints from various aspects: politics, business, health and education. The presence of technology in educational field gives enormous benefits in enhancing the quality of education. Technology can be used as one of sources and learning media which is effective and capable of changing a conventional learning into a modern one (Musahrain, 2016). Because of that, learning processes are no longer centered on the educator, but on the learners.

A smartphone is a form of technology which has brought many impacts in human's life. According to Oxford Dictionary, a smartphone is a mobile phone that performs many of the functions of a computer, typically having a touchscreen interface, internet access, and an operating system capable of running downloaded apps. In fact, it works as a computer but this device is small enough to fit in a user's hand. According to the latest report from e Marketer (2016), the number of smartphone users in Indonesia has risen from 55 million in 2015 to 92 million in 2019. Currently Indonesia has already become the third-largest smartphone market in the Asia-Pacific region, after China and India. Today, Indonesian citizen experience a fast changing lifestyle related to information and communication technology (ICT) utility, such as gadget and internet.

In fact, the number of smartphone users in Indonesia has been growing between $30 \%$ and $50 \%$ each year and this growth momentum will remain intact due to the availability of affordable $4 \mathrm{G}$ smartphones on the Indonesian market and further development of Indonesia's 4G network. Moreover, Indonesia's expanding middle class is increasingly using smartphones in their daily activities, including e-commerce, video calling and streaming. This is also part of a new lifestyle, particularly in the urban regions (e Marketer, 2016). Coming to the $21^{\text {th }}$-century, people enjoys the advantages of data, information and knowledge from one hand, but 
from the other hand they are also perplexed by the information overload, information explosion, false information and misuse of knowledge. The convergence of portable personal technologies, unfiltered access to information, and user-generated content profoundly impacts how this generation era grows and learns. There are more threats coming from contents shared through gadget, such as violence, cyber bullying, online predator and moral-value paradigm shifting (Rahmah, 2015: 94). It is a fact that technology is like a two-eyed knife, it can have positive as well negative impacts.

These days, the use of smartphones for internet purposes has been increasing and even has become a daily need for students. Smartphones make students and teachers easier to collaborate. Smartphones also provide an access to many learning resources for modern society. Moreover, studies have suggested that the use of mobile phone in teaching and learning process have brought significant benefit, especially in teaching English as a foreign language. A study shows that students have positive perceptions towards the use of smartphones, especially the use of mobile phones' applications to learn English (Machmud, 2018: 33-34). Because of that, designers or educators can take this chance to deliver learning materials for them.

Research has proved that the pedagogy gets positively affected by the use of ICTs. Through the use of ICTs, the teachers are made to adopt student-centred as against the teacher-centred approaches. The use of ICTs encourages team work and promotes higher order thinking in students (Majoka, Fazal and Khan, 2013: 41). Among the ICT tools mostly owned and used among people are smartphones. In this context, smartphones are one of the ICTs that can be used for teaching and learning purposes. These tools can provide suitable learning platforms because they have a lot of applications that can be used by teachers and learners in their academic activities.

Considering trends and issues above, Centre for Radio Media Development in Education and Culture or Balai Pengembangan Media Radio Pendidikan dan Kebudayaan (BPMRPK), an institution under the Educational Information Technology and Communication Centre of the Ministry of Education and Culture, has tried to contribute in developing audio based media for teaching and learning purposes. It's in line with the task and function of BPMRPK, i.e. is to develop audio and radio media for education and culture. One of the model being developed was English audio media for teaching speaking skills among senior high and vocational school students.

In fact, audio has some advantages to be used as a teaching and learning medium. First, it is much easier to make an audio clip or podcast than video clip or simulation. Second, audio requires far less bandwidth than video or simulations. Third, it is easily combined with other media, allowing more than one sense to be used and allowing for 'integration'. Next, audio combined with text can help develop literacy skills or support students with low levels of literacy (William, 2015; 278). Moreover, audio media is also suitable for teaching and learning language, especially listening and speaking skills.

Actually, there are four skills which are important in learning English: listening, speaking, reading, and writing. All those skills are supported by some components 
such as vocabulary, grammar, pronunciation, etc. Speaking is an important skill which becomes the key to communicate with other people. Actually, students understand when they read English texts but most of them have no skill to speak English fluently. Moreover, since English is a foreign language in Indonesia, most of the students, especially senior high and vocational school students are not familiar with it.

As a foreign language, most of students would rather use English inside the class than outside the class. Although the students only have limited time to practice English inside the class, they still do not have enough encouragement to practice English outside the class in order to get familiar with English. This case brings some problems that make senior high and vocational school students have difficulties to communicate in English. In contrast, the main goal of teaching speaking is communicative efficiency. Thus, teaching speaking means helping learners to develop their ability to interact successfully in the target language and to do so, one must have communicative competence. In order to help students enhance their speaking skills, a teacher must help the students to improve their grammar, enrich their vocabulary and manage interactions in terms of who says what, to whom, when, and about what (Al Nakhalah, 2016: 96).

Speaking is considered as the most important skill for EFL learners in Indonesia. However, listening and speaking are often neglected in the process of teaching and learning English in Indonesian school context. This is because formal classes in Indonesia mostly emphasize on the students' ability to read and write rather than to listen and speak. In fact, a large percentage of the world's language learners study English in order to develop proficiency in speaking. In fact, the success of learning a language is determined by the ability to communicate in that language. Therefore, many schools in Indonesia have been attempting to improve their students' English speaking proficiency through several programs such as English conversation club, English extra program or sending their students to an English course and so on (Amrullah, 2015: 18).

Due to the current status of English as a foreign language in Indonesia, a few people use it in their daily communication. Probably several people speak English in their daily life such as English students in universities, English courses or in international workplaces. However, to find high school students in Indonesia speaking English in their daily life is almost impossible. It happens because the national system of English education does not focus on the students' speaking ability since the main focus is reading ability. Although several schools have already adopted the 2013 curriculum which emphasizes the students' productive skills, it still seems that the teachers continue to do the same activities in the formal class (Amrullah, 2015: 19). Ideally, the teaching and learning of the four language skills (reading, writing, listening, speaking) can be done in a balanced manner based on its proportions. Then, none of the skills is ignored in the process of teaching and learning.

Indonesian learners commonly have not attained a good level of oral English proficiency. As the ability to speak English is a very complex task, not all of the students in an EFL speaking class have the courage to speak. Many of the students 
feel anxious in a speaking class and some are likely to keep silent. Students attending a speaking class often felt anxious due to pressure from the speaking tasks which require them to present individually and spontaneously within limited time. Moreover students often keep silent because they are lack of confidence, lack of prior knowledge about topics being discussed, and because of poor teacher-learner relationship. In this case self-confidence seems to be the first challenge to overcome for Indonesian students to improve their speaking skills (Widiati and Cahyono, 2006: 11-12).

In relation to the concern related to the problems encountered by the students in developing their speaking ability, it is considered important to develop a model of offline interactive learning audio media for high school and vocational school students. The creative and innovative learning media can be set as one of the English learning resources especially for improving speaking and listening skills. The development of this learning model adopted the constructivism theory which focused on the students so that they were able to learn independently and constructed knowledge through experiences and cognitive interaction. Thus, the purpose of this research was to develop a model of offline interactive learning audio media for high school and vocational school students in order to increase their confidence in practicing conversation in English. The development of this model is actually adopted the stages of application development: planning, analysis, design, implementation, and maintenance (Dennis, Barbara and Tegarden, 2015: 1).

\section{LITERATURE REVIEW}

\section{Constructivism Theory in Language Learning}

The basic premise of constructivist theories is that people create their own meaning through experience. There are two main principles in constructivism: knowledge is constructed and a learner is an active creator. Constructivism suggests that the learner needs to be proactive in how they learn, taking new information, and shaping it to their understanding, rather than just sitting still and passively absorbing information like a sponge (Aljohani, 2017: 98). Then hopefully joyful learning will take place and there is no feeling of being depressed to learn. Students will not be afraid to ask and express their ideas without being laughed at or being underestimated.

The most important thing in constructivism theory is that in a learning process, learners should get the emphasis. They must actively develop their knowledge and must be responsible for their own learning outcomes. Their creativity and liveliness will help them to stand alone in their cognitive life. Then learning is directed at experimental learning. Therefore, the accentuation of educating and teaching is not focused on the educator but on the learners so that the priorities are creating real learning in a relevant context, giving priority to the process, inculcating learning in the context of social experience, and learning in order to construct experience. Therefore, learning is seen as the compilation of knowledge from concrete experiences, collaborative activities, and reflections and interpretations whereas teaching means organizing the environment so that learners are motivated in exploring meaning and 
appreciating uncertainty. On this basis, a learner will have a different understanding of knowledge, depending on his experience, and the perspective used in interpreting it (Suhendi and Purwarno, 2018: 89).

Actually, constructivism is a way of learning and thinking. It is how students make sense of the material and how they can be taught most effectively. Then, the fundamental basis of learning was discovery. Learners construct new understandings using what they already know. They come to learning situations with knowledge gained from previous experiences. That prior knowledge influences what new or modified knowledge they will construct from the new learning experiences. Then, learning is active rather than passive. Learners negotiate their understanding in light of what they encounter in the new learning situation. If what learners encounter is inconsistent with their current understanding, their understanding can change to accommodate new experience. Learners remain active throughout this process (Mvududu and Thiel Burgess, 2012: 110).

In fact, learning English involves cognitive processes, cultural processes and language processes. English language learners pose a particular challenge as they represent such a wide range of academic abilities, language abilities, academic background and cultural differences (Mvududu and Thiel Burgess, 2012: 112). Then, there are three important preliminary key principles: learner readiness, spiral organization, and discovery learning. Motivation is an important part of learning so that instruction must be adapted to the learner's cognitive abilities, experiences and contexts that make the student willing and able to learn. Instruction must be structured such that the learner continually builds upon what he/she has already learned. Then, the learner learns by gathering information for himself/herself, testing the information and formulating rules (Demirezen, 2014: 313-314). These principles are important to be implemented in designing and developing SMILE model.

\section{Learning Speaking in Indonesia Context}

Learning to speak a foreign language requires more than knowing its grammatical and semantic rules. Learners must also acquire the knowledge of how native speakers use the language in the context of structured interpersonal exchange. Because of that, it is difficult for learners, especially adults, to speak the target language fluently and appropriately since oral communication requires the ability to use the language appropriately in social interactions (Shumin, 2002: 204). Because of that, giving exposures to learners how a language is used in an appropriate situation and context is needed.

In an article published b ELT News (2017), language is a tool to express ideas.

It is a means of communication where speech takes place. Without speech, a language is reduced to a mere script. Moreover, any gap in communication results in misunderstandings and problems. Apart from that, humans are designed to communicate orally. According to some studies, a student with fluent conversational skills will often learn to read and write more quickly than a student who is less fluent, whereas a student who is an avid reader may learn conversational skills at a rapid 
rate because they have increased levels of vocabulary. Because of that, teaching the fourth language skills in balance is important in studying a language.

It can be said that having a good speaking skill like a native speaker does is a dream of foreign language students who learn English. However, it is not easy to realize this. Learning another language pronunciation is difficult since some sounds of the target language do not exist in the learner's native language. Bahasa Indonesia, as a mother tongue influences significantly to the way of Indonesian students in pronouncing English sounds. Compared to English, this language generally does not have differences between spelling the letter and pronouncing the sounds (Donal, 2016: 55). Because of that, pronunciation is an important aspect when students learn speaking at the target language.

In the context of foreign language learning, there is a problem which teachers have been aware of for a long time. It is often found that some students who are structurally competent but they cannot communicate appropriately. Because of that, teaching speaking skills is considered necessary component in the English as a foreign language context, including in Indonesia. Unfortunately, English is considered as a foreign language in Indonesia so that very few people use it in their daily communication. English are usually used in limited context such as English students in universities, English courses or in international workplaces (Amrullah, 2015: 1819). Due to this fact, it is hard to find Indonesian students speaking English in their daily life. They usually speaks English in classrooms in limited occasions.

According to the study done to senior high school students in South Tangerang, Banten, it revealed that there were psychological factors such as fear of making mistake, shyness, anxiety, lack of confidence and lack of motivation that hindered students from speaking in English class. It was commonly caused by their fear of being laughed at by the others (Juhana, 2012: 100). In other words, Indonesian students seemed to have low motivation toward speaking English. Most of them considered that speaking English was a difficult skill. They were not accustomed to speaking with their friends, often felt reluctant, and were afraid of making mistakes either in pronunciation, diction or grammar (Amrullah, 2012: 19). Because of that, self-confidence seemed to be the first challenge to overcome in order to improve the speaking skill of the students.

\section{Smart, Mobile, Interactive, Learning (SMILE) Model}

SMILE is an English conversation application that can run on the Android operating system, developed by BPMRPK. It was developed by adopting the fundamental five phase model (planning, analysis, design, and implementation) and is built on the stages of application development: planning, analysis, design, implementation, and maintenance (Dennis, Barbara and Tegarden, 2015: 1).

The planning phase is the fundamental process in identifying the problems, determining the project initiation and the background analysis which reveals what questions, factors, problems and solutions to focus upon. The analysis phase answers the questions of who will use the system, what the system will do, where and when it will be used. The design phase decides how the system will operate in 
terms of the hardware, software, and network infrastructure; the user interface, forms, and reports; and the specific programs, databases, and files that will be needed. The implementation phase is the phase that usually gets the most attention, because for most systems it is the longest and most expensive single part of the development process. It is the stage of a project during which theory is turned into practice (Dennis, Barbara and Tegarden, 2015: 3-4). And the last is the maintenance phase. This phase occurs after the product is in full operation. This phase is less creative than the system design. It is primarily concerned with user training, site preparation, and file conversation. Then if the new information is inconsistent with the design specification, changes have to be made. Hardware also requires periodic maintenance to keep in tune with design specifications. The importance of maintenance is to continue to bring the new system to standards (Singh, 2014: 137). Because of that, it is necessary to evaluate and update the system periodically.

\section{The Adjustment of SMILE Material Development to English Curriculum}

Curriculum plays an important role in the education field. The success of students will be determined by assessment criteria and learning indicators that have been set in the curriculum. In Indonesia, students usually do not have the chance to practice their English since their environments still use Bahasa Indonesia and local languages in every aspect of daily life. Here, English is still regarded as a foreign language so that much language learning occurs in the classroom (Reswari, 2018: 6). Curriculum is expected to answer both the needs and the challenges to improve the quality of education in Indonesia. Because of that curriculum is an inseparable part of education in Indonesia.

Theoretically, curriculum development can occur at any time according to the needs and developments in the implementation of education. It is something which is unnecessary to be worried. However, in line with the English curriculum taught in schools, the SMILE model refers to the communicative approach in teaching the language. The types of expressions referred to are covered in topics of discussion/themes that are close to the lives of high school and vocational school students. Actually, the general purpose of the development of SMILE is to help the students improving their English language skills, especially their speaking and listening skills. Moreover, it is hoped that SMILE can be used to increase the selfconfidence of students in speaking English.

Actually, teaching speaking based on the communicative approach involves speaking activities that tend to follow the same basic pattern: Engage-StudyActivate. Then the topic or theme presented must be interested for students. The first is "Engage". The activities and materials to engage students can be composed by games, music, discussions, stimulating pictures, dramatic stories, amusing anecdotes, etc. The second is "Study". Here, students are asked to focus on language or information and how it is constructed. Some typical areas that involve the study can be the practice of sounds (phonetics), the study of the grammar tenses, functions, pronouns, etc. The next section is "Activate". This section provides students an opportunity to put in practice everything that was previously learned. The 
activities usually include: role-plays, drama activities, discussions, drawings, dialogues, etc. (Zardini and Barnabe, 2013: 35).

\section{METHOD}

SMILE is an English conversation application that can run on the Android operating system, developed by BPMRPK. This model was developed by adopting the fundamental phase model: planning, analysis, design, implementation and maintenance.

The first phase taken in developing SMILE was planning. The fundamental process in this step was identifying the problems, determining the project initiation and the background analysis which was done through observation and literature study. Observation method was done in order to know the habits of senior high school and vocational school students in using smartphones. Literature study was carried out by studying scientific journals related to the issues being discussed, for example the problems of speaking English for Indonesian students, the use of mobile phone applications for learning a language, and the development of interactive applications.

The concept of effectiveness was the basis for creating SMILE. Mobile apps for learning, usually have a very complex interface, with many layers of menus. Because of that, mobile applications needed to be designed and developed in order to become more attractive and easier to be used by the target learners. An application called usable if its functions could be run effectively, efficiently, and satisfying (Nielsen, 1993). It can be said that effectiveness was related to the success of users to achieve goals when using a software whereas efficiency was connected to the running of the user against the software.

The effectiveness testing to determine whether SMILE application matched to the needs of users was done in three steps, namely (1) the requirements analysis or needs analysis, (2) design/testing/development, and (3) installation. Needs analysis of English conversational application for high school students and vocational school students was held in Medan (North Sumatra), Payakumbuh (West Sumatra), Gorontalo, Ruteng (East Nusa Tenggara), Mataram (West Nusa Tenggara), Bandung (West Java), and Yogyakarta (Special Region of Yogyakarta) on the $14^{\text {th }}$ up to March 17, 2017. There were two objectives in doing this, namely (1) to collect data of students and teachers in order to reveal the user profiles and the analysis of the task; (2) to collect data and information about the materials of English language learning as stated in the 2013 Curriculum for high school and vocational school students.

The stages of designing, testing and the development of the model were carried out sequentially. As the design had been compiled, the prototype was made. During the preparation process of the design and the development phases, learning material experts, instructional media experts, and an application developer, and audio voice actors were involved in this project. The learning material experts were responsible for the content of the materials being developed. Instructional media 
experts were responsible for the display of the media content whereas the application developer was responsible to the SMILE application programming module and the insert of the audio files into the programme. The methods used in the preparation of the design and development were interviews, focused group discussions, and experiments.

Furthermore, the limited scale prototype trials were carried out simultaneously with the needs analysis, namely in seven provinces with high school / vocational school students and teachers as respondents. The instruments used were questionnaires and interview guides. This evaluation was conducted to determine the quality of the SMILE model prototype products, covering aspects of media display, programming, learning, and content, with the aim of improving and revising the product. The analysis technique used was descriptive statistics. This analysis was intended to describe the characteristics of the data in each variable or aspect. In this way it was hoped that it would facilitate in understanding the data for the subsequent analysis process. Then, the results of data analysis were used as a basis for revising the products. The prototype test results were followed up by fixing several parts in script writing, audio recording and editing, writing application program modules, and inserting audio into the application program.

\section{RESULT AND DISCUSSION}

\section{The Planning Phase}

The planning phase is the fundamental process in identifying the problems, determining the project initiation and the background analysis which reveals what questions, factors, problems and solutions to focus upon. The developer of the SMILE model considered facts and data that occured in the world and Indonesia regarding the development of information and communication technology, penetration of Internet users in Indonesia, internet usage activities, aspects of education in Internet use, the number of smartphone users in Indonesia, and the most widely used smartphone operating systems in this world.

In the late 2000s, the development of ICT in Indonesia for learning began to be marked by the emergence of learning tools and free learning content, which could be accessed by teachers and students. The use of ICT in learning Indonesia has a long history, starting from the program of organizing educational radio broadcasts or Siaran Radio Pendidikan (SRP), educational television, and mobile education. These has been done in efforts to disseminate information to educational units spread throughout the archipelago. The main disadvantage of radio broadcasts and educational television is the absence of instant feedback. Broadcasts are in the same direction, that is, from resource persons or facilitators to students. Computer technology capable of processing and presenting multimedia shows (text, images, graphics, sound, and animation) provides new opportunities to overcome these weaknesses. Internet technology-based learning provides opportunities to interact, both synchronously (real time) and asynchronous (delayed). Internet-based learning 
allows the learning process between teachers and students to be done anywhere and anytime.

The positive atmosphere regarding the portrait of the trend in the use of smartphones was released by WeAreSocial in collaboration with Hootsuite in a report titled 2018 Global Digital Report (Ramadhan, 2018). It was stated in the report that the number of internet users in Indonesia in 2018 had reached 132 million people. This number indicated that half or more than $50 \%$ of Indonesia's population could access the Internet. It was also explained that of the hundreds of millions of Internet users in Indonesia, 60\% had accessed the Internet using smartphones. In terms of time to use the Internet, Indonesia was ranked fourth in the world with an average duration of using the Internet for 8 hours 51 minutes every day. This ranking of Indonesia exceeded other developed countries, such as Singapore $( \pm 7$ hours 9 minutes), China ( \pm 6 hours 30 minutes), United States ( \pm 6 hours 30 minutes), and Germany ( \pm 4 hours 52 minutes).

Internet usage was dominated by socializing activities in cyberspace. $49 \%$ of the population of Internet users in Indonesia has social media, even Indonesia was the third largest country with a growth rate of $23 \%$ or 24 million users in the past year for the growth of social media users. Indonesia also occupied one of the highest ranking in the world for a long duration using social media (Facebook, YouTube and Instagram), which was equal to 3 hours 23 minutes. It could be said that Indonesians allocated almost $30 \%$ of their time to social media, his duration when compared to the total number of Indonesians using the Internet,

WeAreSocial (Ramadhan, 2018) placed Indonesia as the world's 7th most optimistic country that sees the Internet as a technology that was able to open up many new opportunities, and not as a technology that provides a threat. The survey results of APJII or Association of Indonesian Internet Service Providers (APJII, 2017) showed that as many as $16.68 \%$ of Internet users in Indonesia in 2017 were 13-18 years old. When viewed from the economic level of Internet users, $74.62 \%$ of internet users in Indonesia come from the lower middle social economic strata. For the use of the Internet in the education sector, it was known that $55.30 \%$ of users use the internet to read articles, $49.67 \%$ of users use the Internet to view video tutorials, $17.85 \%$ for online courses, and $14.63 \%$ for registering schools.

The next fact that should be considered as the basis was that the smartphone market in the world was still dominated by the Android and iOS operating systems. In 2015, data from the Annie App (Abidin, 2016) stated that the most downloaded applications by smartphone users came from the Google Play Store (60\%), followed by Apple App Store users. This growth widened almost $100 \%$ in 2016 . The significant increase in the number of downloaders in the Google Play Store worldwide, mainly from developing countries, such as Brazil, India, Indonesia, Turkey and Mexico.

Considering the phenomenon of the rapid development of information and communication technology in accordance with the data submitted by a number of research institutions above, the Centre for Radio Media Development in Education and Culture or Balai Pengembangan Media Radio Pendidikan dan Kebudayaan 
(BPMRPK) of the Ministry of Education and Culture contributed to the development of educational audio / radio media using smartphone technology based on audio. The advantages of audio media were in language learning, especially for developing listening and speaking skills. Therefore, in 2017 BPMRPK designed an offline interactive learning media model for English conversation especially for high school / vocational students. The reasons for determining the object were: (1) many high school / vocational school students used smartphones; (2) offline method was selected so that users can save on internet usage data; (3) interactive concepts was chosen to increase the user involvement in English conversation learning; and (4) English conversation skills were chosen because in the current global era, high school / vocational school students were expected to master conversations, which included vocabularies, expressions, and pronunciation.

Formulation of the problem in this design: "How to provide alternative English conversation learning for senior high/ vocational school students using offline and interactive audio media?" The formulation of this problem would be answered in the following stages in the development of the SMILE model.

\section{The Analysis Phase}

The analysis phase answers the questions of who will use the system, what the system will do, where and when it will be used. A needs assessment is a systematic approach to studying the state of knowledge, ability, interest, or attitude of a defined audience or group involving a particular subject (McCawley, 2004:3). The results of processing data from Needs Analysis in the Development of English Conversation Application Models for Senior High School / Vocational Students held in seven provinces in March 2017 showed that the age of student respondents ranged from 14 to 18 years. Most respondents were accustomed to using smartphones than computers. The majority of respondents used their own smartphones. Those smartphones can be connected to the Internet because their parents provided data packages for them. The respondents used smartphones every day, usually for telephony, sms/chat, and study. Student respondents showed a very great desire to learn the English language, particularly the conversation in English, through smartphone. It was revealed that when the students used the application of English conversation, what they needed were: (1) giving time for a user to imitate sentences in the conversation; (2) recording the sentences spoken by the user; and (3) giving play back to the user after recording their voices to find out the user's weaknesses in English conversation. All respondents wanted this application model can be operated on Android, iOS, and Windows Phone Market.

Respondents of English teachers in 7 (seven) provinces revealed that topics that were in accordance with the 2013 Curriculum were as follows: self-introduction, traveling, family life, jobs, tourism, mass media, social issues, simple technology, matches / competitions in the school environment, hotels/inns, environment, culture, and technology. Respondents of English teachers also revealed that phrases/sentences were in accordance with the 2013 Curriculum were: (a) giving and requesting information; (b) congratulating and responding to it; (c) giving and 
requesting information regarding suggestions and offers; (d) giving and requesting information regarding opinions and thoughts; (e) offering services, and responding to them; and (f) giving and requesting information regarding presuppositions followed by orders/ suggestions.

The results of processing data from teacher and student respondents indicated that the SMILE application was easy to learn, the content was easy to understand, the menu display was quite easy to remember. The availability of voice commands and voice instruction in the SMILE application was easy to use, even though the prototype that had been demonstrated was not perfect.

\section{The Design Phase}

The design phase decides how the system will operate in terms of the hardware, software, and network infrastructure; the user interface, forms, and reports; and the specific programs, databases, and files that will be needed. In fact, the application of SMILE uses voice recognition technology which is currently being developed by the Google Company. The basic concept of voice recognition is recognizing sound and processing it into a command. Voice recognition is a process to convert an acoustic signal (sound) through a microphone that is on a smartphone as an application operating command. In other words, voice recognition has a simple activity that tells the user to talk to the application. The reason why SMILE uses Google's voice recognition technology because currently, it is the most complete voice recognition application on Android which has supported many languages including Indonesian.

The simple logic of the SMILE application is as follows. First, it receives requests for voice recognition. Next, it checks the availability of applications for voice recognition and then if the voice recognition application is available, it changes the sound to a command to run the tools in the application. Here is the mockup of the SMILE model on a smartphone.

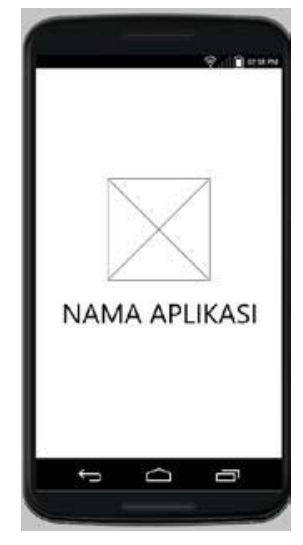

Figure 1. First Display of Mockup

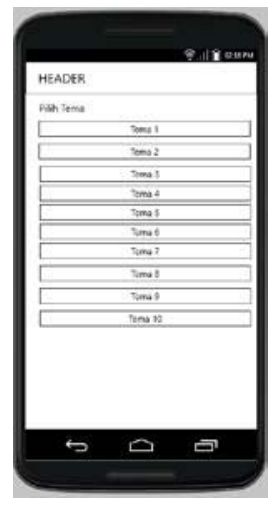

Figure 2. Display Themes of Mockup 
If we call the SMILE application, we will see a welcome screen like in Figure 1. After some time, the application will go to the MENU page which contains themes (Figure 2). This is where a collection of themes for English conversations is provided which we will choose through voice commands. For example, we just have to say "theme 1 " to select the Theme menu 1. The application will then process our sound into a command to press the Theme 1 button.

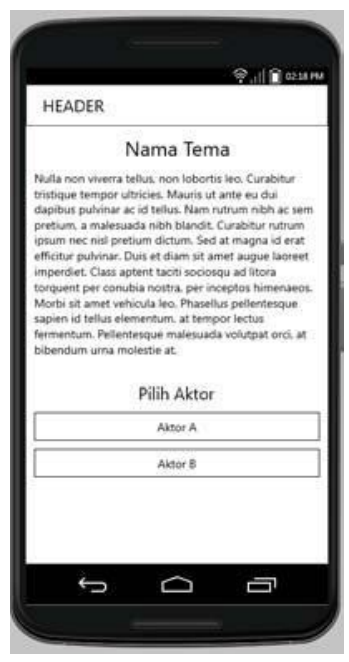

Figure 3. List of Themes of Mockup

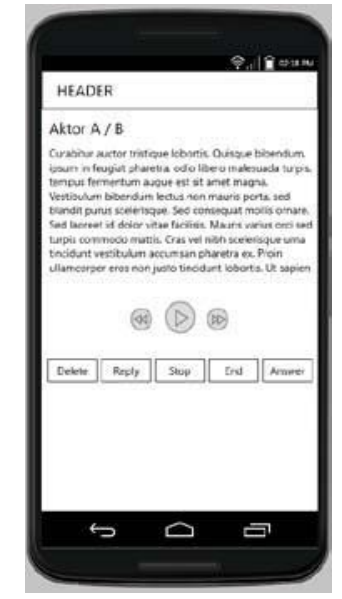

Figure 4. Actors of Mockup

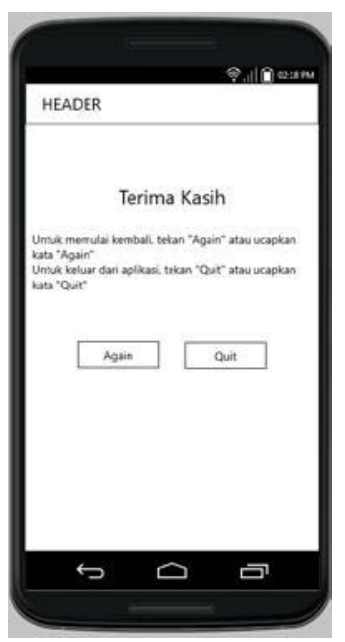

Figure 5. Final Display of Mockup

If we have chosen one of the themes through a voice command, then the display will appear in Figure 3. On this page, we have entered the theme that we have chosen. Then the conversation text is displayed on the page, and two role buttons are provided. For example, if we say "Actor A" then the application will go to the Actor A page as seen in Figure 4. On this page there is also a conversation text and buttons 
that we can see. And if we say the command "end "then the application will go to the final page (Figure 5).

Flowchart in the delivery of material or the course of English conversation applications for high school and vocational school students shown in Figure 6 . The SMILE application was developed using Android Studio 2.2 software with a folderbased programming language.

When entering the production stage of the SMILE application, there are a number of conditions for inserting audio into the application program language. Because between audio and program language must be appropriate, so as not to confuse users. These conditions are as follows:

a. There must be one keyword to call all the desired files. For example: the keyword "lesson 1" can be used to call all files in the lesson 1 folder.

b. The database has been made a template to the maximum, but it does not rule out the possibility of changes, and it will still be in the form of a template.

c. The size of the audio recording should be below $320 \mathrm{kbps}$ to save the size of the application file.

d. Naming audio files is set.

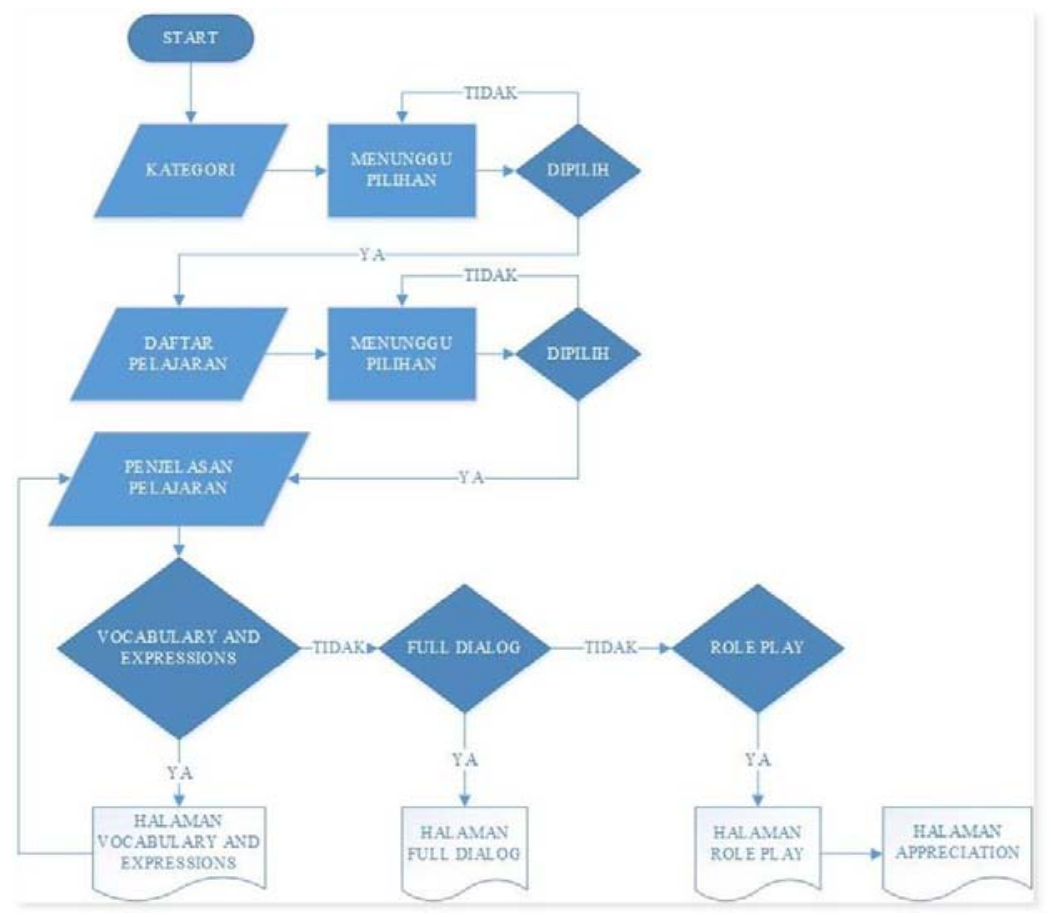

Figure 6. Flowchart of the SMILE application 
Referring to the flowchart of SMILE model application, it can be explained that:

a. Standard Opening Page is a page that provides information and instructions to users about the stages passed in learning English conversations through the SMILE application.

b. The Category Page contains a list of categories compiled based on the types of expressions according to the English Language 2013 Curriculum for senior high/vocational school. For example: Introduction.

c. Lesson List Page contains lesson titles grouped by category. For example: Lesson 1 "My name is Susan."

d. Explanation of the Selected Lessons Page contains the greeting of the narrator, explains the types of phrases and title of the lesson.

e. Vocabulary and Expressions page contains fragments of sentences that have appeared in the full dialogue, and the narrator defines them in Bahasa Indonesia.

f. Full Dialogue Page allows users to listen: 
- The voice of the narrator that explains the actors and conversation context in Indonesian.

- Short music marker (4 ")

- Full dialogue / conversation between two native speakers (1 male and 1 female) in English.

- The actors referred here are roles, not just names. For example, conversations between doctors and patients, flight attendants with passengers, tour guides with tourists, etc.

g. Role Play Page (role 1 and 2). This page gives the opportunity for users to interact with the application by choosing the role that the user likes, then he will say a dialogue from that role. Given the use of blind people who cannot read the dialogue in writing, a voice guidance is provided in the role, to make it easier for the user to pronounce the sentence. In addition, the Role Play page gives the opportunity for user to record his voice. The sequence is repetitively until role rotation is complete (see Figure 7).

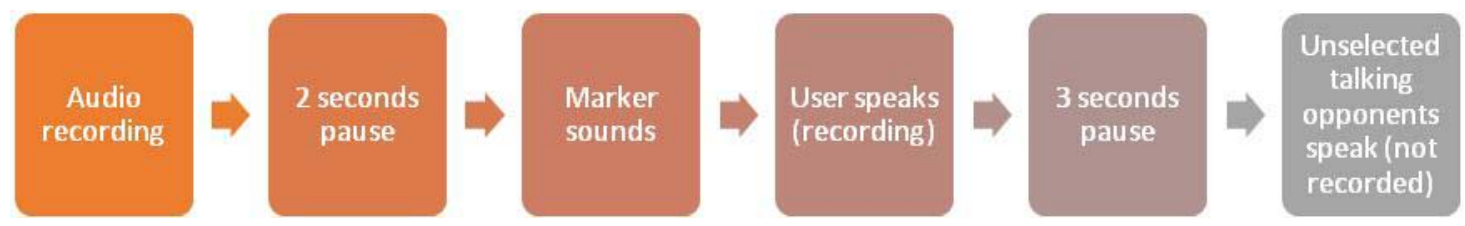

Figure 7. Sequences in Role Playing

h. Listening Pages (Review) allows users to listen to the record again while playing a role and be given the option to delete the recording.

i. Appreciation page rewards users for using the SMILE application to learn conversations about certain types of expressions, so that users can be more confident in conversing in English. This page also encourages users to continue using the SMILE application so that their English conversations can be more fun.

Script writing in SMILE conversation applications is presented in the form of audio and application/ display, as can be seen in Figure 8. This is an excerpt from the full text, especially in the full dialogue section. 


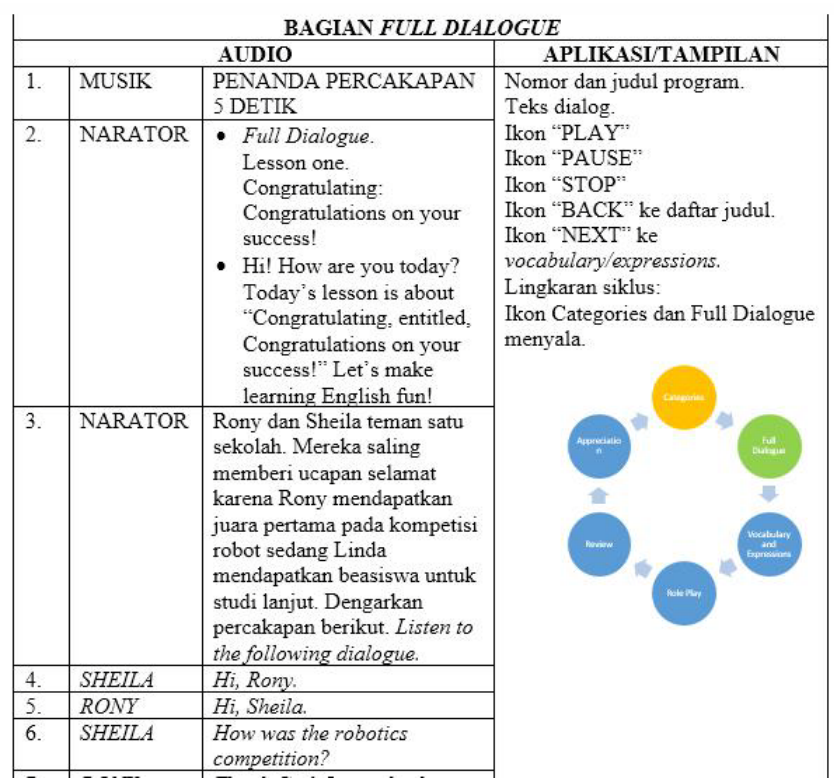

Figure 8. Script Format for the SMILE Application Model

Script writers need guidance on the contents of the media as a basis for script writing. This guide is called the Media Content Outline or Garis Besar Isi Media (GBIM), as can be seen in Figure 9.

Format Garis Besar Isi Media (GBIM)

Model Media Smile Percakapan Bahasa Inggris Interaktif Untuk Siswa SMA/SMK

A. Identifikasi

\begin{tabular}{|l|l|l|}
\hline Judul Program & $:$ & \\
\hline Kode & $:$ & \\
\hline Sasaran & $:$ & \\
\hline Durasi Audio & $:$ & \\
\hline Penulis & $:$ & \\
\hline Pengkaji Materi & $:$ & \\
\hline Pengkaji Media & $:$ & \\
\hline
\end{tabular}

B. Rancangan GBIM

\begin{tabular}{|c|c|c|c|c|c|c|c|c|}
\hline No. & Tema & $\begin{array}{c}\text { Sub } \\
\text { tema }\end{array}$ & Judul & $\begin{array}{c}\text { Ketrampilan } \\
\text { Berbahasa }\end{array}$ & $\begin{array}{c}\text { Kompetensi } \\
\text { Indikator }\end{array}$ & $\begin{array}{c}\text { Materi } \\
\text { Pokok }\end{array}$ & $\begin{array}{c}\text { Contoh } \\
\text { Ungkapan }\end{array}$ & $\begin{array}{c}\text { Daftar } \\
\text { Pustaka }\end{array}$ \\
\hline (1) & $(2)$ & $(3)$ & $(4)$ & $(5)$ & $(6)$ & $(7)$ & $(8)$ & $(9)$ \\
\hline & & & & & & & & \\
& & & & & & & & \\
\end{tabular}

Figure 9. Media Content Outline Format for the SMILE Application Model 


\section{The Implementation Phase}

The implementation phase is the phase that usually gets the most attention, because for most systems it is the longest and most expensive single part of the development process. The pattern of utilization of the SMILE application is that prospective users download the SMILE application through the Google PlayStore, taking into account the percentage of Android users more than iOS. When downloading, developers only need the downloader's email address to find out whether the downloader is human, and not a robot. When downloading, users need an adequate internet connection support. But when using the SMILE application, users can use it offline.

Users used the Smile application sequentially, starting from the standard opening section (welcome greeting and explanation of the commands needed to activate the SMILE application), categories and lessons section, full dialogue section, vocabulary and expressions, role play parts (role 1 sub-section and conversation rule 2 sub-section), review section (users can listen to their voice recordings, and then decide whether to save or delete the record), and appreciation section.

Users used the SMILE application independently/ individually. The advantage was that users only paid for the Internet connection at the beginning, in the downloading process of the SMILE application. Then, they used this application offline. However, if there was a new topic, the user would receive an email notification, followed by an update application. Developers could monitor the number of downloaders through Google statistics. Therefore, the prerequisite for users when downloading was to provide and inform their emails.

\section{Discussion}

There were two things to be discussed in this section, namely the success criteria for the SMILE Model application and the technical preparation needed for the production and implementation of the SMILE Model. The main goal of developing the SMILE model was the users can learn English conversations independently, interactively, confidently, and pleasantly. Therefore, the success criteria for the SMILE application model were based on these four aspects, as can be seen in Table 10.

\begin{tabular}{|c|l|l|}
\hline No & \multicolumn{1}{|c|}{ Aspect } & \multicolumn{1}{c|}{ Success Criteria } \\
\hline 1. & Independence & $\begin{array}{l}\text { - Do something without the help of others. } \\
\text { - Doing something based on one's own choice rather } \\
\text { than imitating others. }\end{array}$ \\
\hline 2. & Interactive & $\begin{array}{l}\text { - Generating motivation, interest or passion for } \\
\text { student learning. } \\
\text { - Stimulate students' desire to learn more, such as } \\
\text { interacting with teachers and other students. } \\
\text { - The learning model must be able to provide }\end{array}$ \\
\hline
\end{tabular}




\begin{tabular}{|c|c|c|}
\hline & & $\begin{array}{l}\text { opportunities for students to give their responses to } \\
\text { the material presented. } \\
\text { - Ensure the development of student personality } \\
\text { activities. } \\
\text { - Educate students in self-learning techniques and } \\
\text { how to obtain knowledge through personal effort. } \\
\text { - Instill and develop the values and attitudes of } \\
\text { students in everyday life. }\end{array}$ \\
\hline 3. & Fun learning & $\begin{array}{l}\text { - Creating an environment without stress, a safe } \\
\text { environment to make mistakes. } \\
\text { - Ensure that teaching materials are relevant to their } \\
\text { benefits and interests in meeting student } \\
\text { expectations. } \\
\text { - Ensure that the learning process can take place } \\
\text { emotionally and positively, } \\
\text { - Engage consciously all the senses and also the } \\
\text { mind of the left brain and right brain. } \\
\text { - Challenging students to be able to think far ahead } \\
\text { and express what is being learned by mobilizing } \\
\text { optimal intelligence to understand teaching } \\
\text { materials. } \\
\text { - Consolidating teaching materials that have been } \\
\text { studied by reviewing them in relaxed periods. }\end{array}$ \\
\hline 4. & $\begin{array}{l}\text { Learning that } \\
\text { increases self- } \\
\text { confidence }\end{array}$ & $\begin{array}{l}\text { - Confidence in his abilities. } \\
\text { - Showing optimism in doing things. } \\
\text { - Showing attitude does not hesitate to do something. } \\
\text { - Do not show a confused attitude when doing } \\
\text { something. }\end{array}$ \\
\hline
\end{tabular}

Table 10. Criteria for Success of the SMILE Application Model

Considering the production process of the SMILE application was not only related to audio, but also required a training in human resources (HR) for media reviewers and production technicians to develop application-based audio media models, especially Android. In utilizing audio media, the support of facilities which was needed as follows:

- PCs / laptops / netbooks were multimedia ready and have at least 4 GB of internal or external memory

- Android based smartphone

- Internet connection to download the SMILE Application for the first time

- The output of the media player uses the loudspeaker for shared learning; headphones/ earphones for independent/ individual learning 
- $\quad$ The power or energy used by the rotator was a battery (unidirectional/ DC power source), electricity (alternating power source/ AC).

Socialization was carried out massively in order to reach or reach as many users as possible. Management or maintenance of audio media English conversations were conducted regularly by sending email notifications to the downloaders when new topics are launched. This notification was needed so that downloaders were always updated with themes or topics developed by BPMRPK. Users had to update the application if a new topic was launched.

\section{CONCLUSION AND SUGGESTION}

Currently Indonesia has already become the third-largest smartphone market in the Asia-Pacific region, after China and India. Today, Indonesian citizen experience a fast changing lifestyle related to information and communication technology (ICT) utility, such as gadget and Internet. Unfortunately, the use of the Internet in Indonesia for educational purposes is mostly focused on reading articles and viewing tutorial videos. Data from research institutions have not revealed the use of the Internet or applications for learning English, especially conversations in English.

In the midst of the sophistication of information and communication technology, audio media is the most appropriate medium for teaching and learning languages, especially in listening and speaking skills. Of the four important skills mastered in learning English, speaking is a key skill for communicating with others. Actually students understand the contents of the English texts they read but most students cannot speak English fluently. Next, English is a foreign language in Indonesia. Because of that, most senior high school / vocational school students are not accustomed to using English in their daily conversation. Students prefer practicing English in their classrooms to practicing it outside the classrooms. They are not brave and confidence enough to practice English in their daily lives, even though the main purpose of teaching speaking is to communicate efficiently. In addition, the percentage of students' needs for advanced schools in Indonesia and abroad has been increasing as the English speaking skills become one of the requirements that must be fulfilled.

Based on the reasons above, there is a need for the birth of an interactive and offline English language learning audio media model that can be used improve the skills of senior high school / vocational students in terms of listening and speaking. This audio media have to be fun, can increase the students' confidence in speaking English, and use the latest technology. The purpose of this research was to develop a model of offline interactive learning audio media for high school and vocational school students in order to increase their confidence in practicing English.

Smart, Mobile, and Interactive Learning (SMILE) Model is an English conversation application that can be run on the Android operating system, developed by BPMRPK. It was developed by adopting the fundamental four phase model (planning, analysis, design, and implementation). The SMILE model was developed 
by involving English learning material experts, audio media experts, and application developers. Various methods of collecting data are used in the planning, analysis and design stages, such as observation, interviews, focused group discussions, and experiments.

Actually, the development of SMILE Model was still at the design phase, especially after the evaluation of the prototype model was carried out in seven provinces (East Nusa Tenggara, West Nusa Tenggara, Gorontalo, West Java, Yogyakarta, North Sumatra, and West Sumatra) were done. Therefore, the development of this model needs to be continued to the next stages so that the SMILE model can be used by senior high school / vocational school students in Indonesia in order to improve their listening and speaking skills in a convenient and fun way by using an Android-based application. In addition, visually impaired students can also use the SMILE model because the main advantage of SMILE Model laid in the voice recognition technology which makes the user easier to give a call or command.

\section{REFERENCES}

\section{Books}

APJII. (2017). Infografis Penetrasi dan Perilaku Pengguna Internet Indonesia: Survey 2017. Jakarta: Teknopreneur Indonesia. Retrieved in August 2018 from https://apjii.or.id/survei2017/kirimlink.

Dennis, Alan; Wixom, Barbara and Tegarden, David. 2015. System Analysis \& Design.

An Object-Oriented Approach with UML. Fifth Edition. United States of America: John Wiley \& Sons, Inc. Retrieved in November 2018 from www.arxen.com/descargas/.../systems-analysis-and-design-with-uml-5thedition.pdf

Rahmah, Amalia. (2015). Digital Literacy Learning System for Indonesian Citizen. Retrieved October, 2018 from https://core.ac.uk/download/pdf/82522006.pdf.

Shumin, K. (2002). Factors to Consider: Developing Adult EFL Students Speaking Abilities. J. C. Richards, \& W. A. Renandya (Eds.), Methodology in Language Teaching. Cambridge: Cambridge University Press. Retrieved in November 2018 from

https://www.academia.edu/34717258/Methodology in Language Teaching.

William, Anthony. (2015). Teaching in a Digital Age. Guidelines for Designing

Teaching and Learning. Canada: Tony Bates Associates LTD Vancouver BC. Retrieved in November 2018 from https://opentextbc.ca/teachinginadigitalage/chapter/9-5-2-audio/ 
Widiati, Utami and Cahyono, Bambang Yudi. (2006). The Teaching of EFL Speaking in the Indonesian Context: the State of the Art. Retrieved in October 2018 from https://www.researchgate.net/publication/242616891.

\section{Journals/ Proceedings/ Dissertations/ Theses}

Aljohani, Muna. (2017). Principles of "Constructivism" in Foreign Language Teaching. Journal of Literature and Art Studies, January 2017, Vol. 7, No. 1, 97-107/2018.02.01. Retrieved in November 2018 from https://www.academia.edu/31002490/Journal of Literature and Art Studies Vol.7 Issue 1 January 2017.pdf.

Amrullah, Ahmad Zubaidi. (2015). Developing Language Games to Teach Speaking Skill for Indonesian Senior High School Learners. JEELS, Volume 2, Number 2, November 2015. Retrieved in October 2018 from jurnal.iainkediri.ac.id/index.php/jeels/article/download/94/96.

Al Nakhalah, Ahmed Maher Mahmoud. (2016). Problems and Difficulties of Speaking That Encounter English Language Students at Al Quds Open University. International Journal of Humanities and Social Science Invention. Volume 5 Issue 12, December 2016. Retrieved on November 2018 from http://www.ijhssi.org/papers/v5(12)/version-3/05120396101.pdf.

Demirezen, M. (2014). Cognitive-code theory and foreign language learning relations. International Online Journal of Education and Teaching (IOJET), 1(5). 309-317. Retrieved in November 2018 from http://iojet.org/index.php/IOJET/article/view/65/92.

Donal, Andri. (2016). Indonesian Students' Difficulties in Pronouncing English Diphthongs. Journal of English Education Vol. 2 No. 2 December 2016.

Retrieved on October 2016 from http://ejournal.upp.ac.id/index.php/jee/article/download/1305/pdf 21.

Machmud, Karmila. (2018). The Smartphone Use in Indonesian Schools: The High School Students' Perspectives. Journal of Arts \& Humanities. Volume 07, Issue 03, 2018: 33-40. Retrieved in October 2018 from https://www.theartsjournal.org/index.php/site/article/view/1354.

Majoka, Muhammad Iqbal; Fazal, Shawana and Saeed, Muhammad. (2013). Implementation of Information and Communication Technologies (ICTs) in Education Course: A Case from Teacher Education Institutions in Pakistan. Bulletin of Education and Research. August 2013, Vol. 35, No. 2. Retrieved in October 2018 from http://www.pu.edu.pk/images/journal/ier/PDFFILES/003\%20Muhammad\%20labal,\%20Shawana\%20\&\%20Saeed\%203753.pdf.

Mvududu, Nyaradzo and Thiel-Burgess, Jennifer. (2012). Constructivism in Practice: The Case for English Language Learners. International Journal of 
Education2012, Vol. 4, No. 3. Retrieved in November 2018 from http://www.macrothink.org/journal/index.php/ije/article/view/2223.

Juhana. (2012). Psychological Factors that Hinder Students from Speaking in English Class (A Case Study in a Senior High School in South Tangerang, Banten, Indonesia). Journal of Education and Practice. Vol 3, No 12, 2012. Retrieved in November 2018 from https://www.iiste.org/Journals/index.php/JEP/article/viewFile/2887/2913.

Reswari, Grindra. P.A. (2018). Teaching English in the KTSP Curriculum and 2013 Curriculum Simultaneously: A Case Study of "A Senior High School in Semarang", Central Java, Indonesia. Retrieved in November 2018 from https://englishagenda.britishcouncil.org/sites/default/files/attachments/girindra putri qub dissertation.pdf.

Singh, Jashanpreet. System Analysis and Design (2014). IRJMST Vol 5 Issue 5 [Year 2014]. Retrieved in November 2018 from https://www.academia.edu/9860817/System_Analysis_and_Design.

Suhendi, Andang and Purwarno. 2018. Constructivist Learning Theory: The Contribution to Foreign Language Learning and Teaching. In the 1st Annual International Conference on Language and Literature, KnE Social Sciences. Retrieved in November, 2018 from https://knepublishing.com/index.php/KneSocial/article/view/1921/4298.

Zardini, Mariana Castaldi and Barnabé, Flávia Herker Lopes. (2013). How to Improve the Speaking Skills through the Communicative Approach. v. 9 • n. 2

- p. 27-43 • jul./dez. 2013. Retrieved in November 2018 from

http://publicacoes.unifran.br/index.php/dialogospertinentes/article/view/776.

\section{Others}

Abidin, R. (2016). Jumlah Download Aplikasi di Google Play Store Kalahkan Apple App Store di Tahun 2015. Retrieved in Januari 9, 2017, from: https://teknojurnal.com/jumlah-download-aplikasi-di-google-play-storekalahkan-apple-app-store-di-tahun-2015

eMarketer. (2016). Indonesia is the 3rd -Largest Smartphone Market in the Asia

Pacific. Retrieved in October 2018 from https://www.indonesiainvestments.com/id/news/todays-headlines/indonesia-is-the-3rd-largestsmartphone-market-in-the-asia-pacific/item6777.

Mccawley, Paul. (2004). Methods for Conducting an Educational Needs Assessment: Guidelines for Cooperative Extension System Professionals. $\begin{array}{llll}\text { Retrieved in November } & 2018 \text { from }\end{array}$ https://www.researchgate.net/publication/255627038 Methods for Conducting an Educational Needs Assessment/download/ 
Ramadhan, Bambang. (2018, Februari 6). Inilah Perkembangan Digital Indonesia Tahun 2018. Retrieved in August 2018 from https://www.goodnewsfromindonesia.id/2018/02/06/inilah-perkembangandigital-indonesia-tahun-2018.

\section{ABOUT THE AUTHORS}

Mariana Susanti: Instructional Technology Developer, Model Production Section, Centre for Radio Media Development in Education and Culture of the Ministry of Education and Culture, Bantul, Yogyakarta, Indonesia

Suparti: Instructional Technology Developer, Model Production Section, Centre for Radio Media Development in Education and Culture of the Ministry of Education and Culture, Bantul, Yogyakarta, Indonesia 